\title{
Anne-Bebek Bağlanma Ölçeğinin Türk Toplumuna Uyarlanmasi: Aydın Örneği
}

\author{
Adaptation of Mother to Infant Bonding Scale to The Turkish Society: Aydın Sample
}

\author{
Hatice Karakulak Aydemir ${ }^{1}$, Özgür Alparslan² \\ ${ }^{1}$ Ankara \\ ${ }^{2}$ Gaziosmanpaşa Üniversitesi Sağlık Bilimleri Fakültesi, Ebelik Bölümü, Tokat
}

\section{ÖZET}

Amaç: Bu çalışma, anne ile bebek ve baba ile bebek arasındaki bağlanmayı ölçmek amacıyla kullanılan Anne-Bebek Bağlanma Ölçeği'nin (ABBÖ) Türkçeye ölçüt bağıntılı uyarlamasının yapılarak, anne ve babalarda geçerlilik ve güvenilirliğini test etmek ve anne ile baba arasındaki farklılıkları açıklamak amacıyla yapılmıştır.

Yöntem: Araştırma metodolojik, tanımlayıcı ve kesitsel (01 Kasım 2007-31 Şubat 2008) bir çalışmadır. Araştırmanın örneklemini, bir devlet hastanesinde vajinal yolla doğum yapan $(n=296)$ kadınlar ve eşleri $(n=215)$ oluşturmuştur. Araştırmanın ilk aşamasında araştırma kriterlerine uyan 296 anne ile ve bu annelerin hastaneye gelebilen eşlerinden sadece $215^{\prime}$ i ile görüşülmüştür. Çalışmanın ikinci aşamasında ise aynı anne ve babalardan, ulaşılabilen 202 anne ve 142 baba ile görüşülmüştür. Araştırmanın verileri tanıtıcı bilgi formu, ABBÖ, Edinburg Doğum Sonu Depresyon Ölçeği kullanılarak toplanmıştır (EDSDÖ). Ölçeğin dil eşdeğerliği sağlanmıştır. Kapsam geçerliği için uzman görüşleri alınmış olup ölçeğin güvenirliği madde-toplam puan korelasyonu ve iç tutarlık analizi ile belirlenmiştir. Yapı geçerliği için faktör analizi yapılmıştır. Veriler açıklayıcı faktör analizi, ölçüt bağıntıı geçerlilik ve test tekrar test çalışmaları yapılarak değerlendirilmiştir.

Bulgular: Ölçeğin içerik geçerliliği Kendall's Uyuşum Katsayısı= W=0,277, $p<0,05$ olarak belirlenmiştir. Temel bileşenler analizi sonucunda ölçeğin annelere uygulanmasında iki faktörlük, babalara ilk uygulanmasında iki faktörlük, ikinci uygulanmasında ise üç faktörlük sonuç elde edilmiştir. ABBÖ'nin anneye ait Cronbach Alpha iç tutarlılık katsayıları birinci aşamada 0.69 , ikinci aşamada 0.68 olarak bulunmuştur. Ölçeğin babaya ait ilk uygulama Cronbach Alpha katsayısı 0.79 ve ikinci uygulama Cronbach Alpha katsayısı 0.72 olarak bulunmuştur.

Ölçek annelerde daha düşük iç tutarlığa sahip olmasına rağmen, tüm maddelerin ölçeğin tutarlığına katkı sağladıkları saptanmıştır (Madde bütün korelasyon katsayıları: $r=.21-.54$ arasında, madde silindiğinde Cronbach Alpha $=.62-.69$ arasındadır.). Babalarda daha yüksek iç tutarlığa sahip olmasına rağmen, bazı maddelerin ölçeğin güvenilirliğine katkı sağlamadığı saptanmıştır (Madde bütün korelasyon katsayıları: $r=.08-.80$, madde silindiğinde Cronbach Alpha $=.66-.85$ arasındadır.).

Annelerde depresyonun bağlanma üzerindeki etkisinin zamanla kaybolduğu, babalarda ise yüksek depresyonun bebeğe olan bağlanmayı azalttığı saptanmıştır.

Sonuç: ABBÖ en az okuma-yazması olan annelerin, bebeklerine bağlanma düzeylerini ölçmede geçerli ve güvenilir bir araçtır. Ölçek babaların bebeklerine bağlanma düzeylerini ölçmede geçerli, ancak güvenilir (iç tutarlık) olmayan bir araçtır.

Anahtar Kelimeler: Bağlanma, Anne-Bebek Bağlanması, Baba-Bebek Bağlanması, Edinburg Postpartum Depresyon Ölçeği

\section{ABSTRACT}

Objectives: This study aimed to make a criterion-related adaptation of the Turkish version of the Mother to Infant Bonding Scale (MIBS), used for measuring the bonding between the Mother to Infant, into Turkish and testing its validity and reliability for mothers and fathers and explain the differences between a Mother to Father.

Method: This is a methodological, descriptive and cross-sectional (1 November, 2007-28 February, 2008) study. The sample of the study consisted of women who delivered vaginally $(n=296)$ in a state hospital and their spouses $(n=215)$. The data of the study were collected using information form, MIBS, and Edinburg Postpartum Depression Scale (EPDS). In the first stage of the study, 296 mothers complying with the criteria and 215 of the husbands who were allowed to enter into the hospita were interviewed. In the second stage of the study, only 202 mother and142 fathers were interviewed. Linguistic equivalence of the questionnaire was established. In order to test content validity, expert opinions were taken. Reliability was tested using item-total correlations and internal consistency analysis. Principal components analysis was conducted in order to evaluate construct validity. The data were analyzed doing exploratory factor analysis, criterion-related validity and test retest studies.

Results: The internal consistency of the scale was determined as Kendall's coefficient of concordance $=W=0,277, p<0,05$. As a result of the principal components analysis, the implementation of the scale to mothers yielded two-factor result, the first implementation to fathers yielded two-factor result and the second implementation three-factor result. The Cronbach Alpha internal consistency coefficient of MIBS to mothers was found to be 0.69 in the first phase and 0.68 in the second phase. The Cronbach Alpha coefficient of the first implementation of the scale to fathers was determined to be 0.79 and the second 0.72 .

Even though the scale has lower internal compliance for the mothers, all the items were found to contribute. (All the item correlation coefficients: $r=.21-.54$, Cronbach Alpha at the item is delated $r=62-.69$ ). Even though it has higher internal compliance for the fathers, some of the items were found not to contribute to the reliability of the scale (All the item correlation coefficients: $r=.08-.80$, Cronbach Alpha at the item is delated $r=.66-.85)$. It was determined that the effect of depression in mothers on bonding disappeared in time, and that high depression in fathers were found to decrease bonding to the baby.

Conclusion: MIBS is a valid and reliable tool in measuring the bonding levels of at least literate mothers to their babies. The scale is a valid tool in measuring the bonding levels of fathers to their babies, but it is not a reliable tool with this respect (no internal consistency).

Key words: Bonding, Mother-to-infant Bonding, Father-to-infant Bonding, Edinburg Postnatal Depression Scale

54. Türkiye Milli Pediatri Kongresi, 9. Milli Pediatri Hemşireliği Kongresi, 20-24 Ekim 2010, Antalya-Mardan'da, e-Poster bildiri olarak sunulmuştur.

Corresponding Author: Özgür Alparslan

Address: Gaziosmanpaşa Üniversitesi Tokat Sağlık Bilimleri Fakültesi Ebelik Bölümü, Taşlıçiftlik Yerleşkesi, 60240, Tokat

E-mail: ozgralp60@gmail.com
Başvuru Tarihi/Received: 08-11-2015

Kabul Tarihi/Accepted: 22-02-2016 


\section{GíRiş}

Bağlanma bebek ile birincil bakım veren kişi arasında gelişen ve bebekte güven duygusunu yerleştiren güçlü bir bağdır (1). Annenin bebekle duygusal bir bağ kurması gebelikle birlikte başlayan, fetüsün hareketleri ile artan, doğumda doruğa çıkan, doğum sonrası yaşamın birinci yılında oluşan etkili bir ilişkidir (2-4). Anne, baba ve bebek arasındaki sıcak duygular, özellikle korkulu ve stresli anlarda birbirlerine sağladıkları rahatık ve destek, bağlanmayı oluşturur. Bağlanma iki taraflı bir ilişkidir ve her iki tarafın da birbirinin intiyaçlarını karşılaması ile gelişir (4).

Kurulan bağın annenin önceki yaşadıkları ve ilk hissettikleriyle büyük ilgisi vardır. Örneğin doğumla birlikte depresyona giren annelerde bu bağ tam olarak kurulamazken, doğumda olumlu duygular hisseden annelerde kurulan bağ oldukça güçlü olabilmektedir. Pek çok annenin bebeğini ilk kez kollarına aldığında ona karşı ilgisiz davrandığı fakat ilk bir hafta içerisinde ona karşı yavaş yavaş şefkat hissettiği ortaya konmuştur. Fakat depresyon geçiren bazı anneler, çocuklarına karsı sevgi besleme konusunda uzun süren problemler yaşayabilmekte ve kendini umutsuz, huzursuz, yalnız hissettiğinde, bebeğine veya çevresindeki insanlara karşı düşmanca duygular besleyebilmektedir (5-7). Postpartum dönemdeki duygusal sorunlar, depresyon yalnızca annenin benlik saygısını değil, çocuklarının bakımını, aile ile ilgili sorumluluklarını ve rollerini de olumsuz yönde etkiler $(8,9)$. Eşler, çoğu zaman annelerin depresyona ilişkin belirtilerine anlam veremez ve ne yapacaklarını bilemezler. $\mathrm{Bu}$ da onların yetersizlik duyguları yaşamasına ve depresyona girmelerine yol açabilmektedir $(7,10)$. Ayrıca erkekler çoğu zaman kendileri için önemli olan kişiler ile ilgili yoğun kaygı yaşadıklarında geri çekilme ya da eleştirme davranışlarında bulunabilmektedir (6).

Anne-bebek, baba-bebek etkileşiminin çocuğun gelişimi ve tüm yaşamını etkilemesi nedeniyle ebe/hemşirelere doğum öncesi, doğum ve doğum sonrası dönemde önemli sorumluluklar düşmektedir. Ebe/ hemşireler profesyonel bir ebelik yaklaşımı içerisinde anne-bebek, baba-bebek ile bağlanma sürecini başlatmaya ve sürdürmeye yardımcı olmalıdırlar (3). Bu dönemde anne ve babayı mutlaka desteklemeleri, iyi bir gözlem ve değerlendirme yaparak uygulamaları aileyi bakıma katmaları önemlidir. Anne-baba ve bebeklerinin ilk birlikteliği dikkate alındığında, anne-bebek bağlanmasını, özellikle baba-bebek bağlanmasını ölçen iyi yapılandırılmış ölçme araçlarına gereksinim duyulmaktadır.

Taylor ve arkadaşları (5) tarafından geliştirlilen "Anne-Bebek Bağlanma Ölçeği (ABBÖ)" ile doğumdan sonraki ilk 12 haftalık sürede anne-bebek bağlanmasının sürekli geliştiği gösterilmiştir (5). Ölçek bu yüzden doğumdan sonraki periyodu hemen değerlendirmek için kullanılabildiği gibi, bağlanmayı yakın bir zaman dilimi içerisinde tekrar değerlendirmek için de kullanılabilmektedir. Genel bir topluluğa uygulanabilecek kendi içerisinde tutarlı, elde edilen sonuçlarla annenin içinde bulunduğu ilk psikolojik durumu gösterecek şekilde hazırlanmış bir ölçektir. Bu ölçeğin toplumumuza kazandırılması ile ebe/ hemşireler, anne-bebek, baba-bebek bağlanma sürecinde profesyonel bir yaklaşım ile sevgi oluşumunu başlatma ve sürdürmeye yardımcı olabileceklerdir. Bu dönemde anne ve babayı mutlaka destekleyerek, iyi bir gözlem ve değerlendirme ile anne-babanın ruhsal durumunu, var olan sorunları erken dönemde belirleyebilecek, uygun yaklaşımda bulunabilecektir (3). Uygulamalara anne-babayı 
katarak, bebeğe sağlanan bakımın kalitesinin artmasına ve bebeğin sağlıklı gelişmesine katkıda bulunabilecektir. Bu araştırmada ABBÖ’nün (Mother-to-Infant Bonding Scale), Türkçeye uyarlamasının yapılarak geçerlilik ve güvenilirliğinin araştırılması ve Edinburgh Doğum Sonrası Depresyon Ölçeği (EDSDÖ) ile anne ve babaların bebeklerine bağlanmasına etki eden ruh halinin belirlenmesi amaçlanmıştır.

\section{GEREÇ ve YÖNTEM}

Araştırmanın Tipi: Araştırma, ABBÖ Türkçe formunun dil uyarlaması, geçerlilik ve güvenilirliğinin değerlendirildiği metodolojik, EDSDÖ ile anne ve babaların bebeklerine bağlanmasına etki eden ruh halini belirleyen tanımlayıcı ve kesitsel bir çalışmadır.

Araştırma, Türkiye'nin batısında bir ilde Doğum ve Çocuk Hastanesi loğusa servislerinde (01.11.2007- 31.02.2008'de) normal vajinal yolla doğum yapan kadınlar ve eşleri ile ev ziyaret yapılarak gerçekleştirilmiştir.

Araştırmanın Örneklemi: Araştırmada örneklem büyüklüğünü saptamada ölçekteki her bir maddenin en az 25 katı olacak şekilde örnekleme alınacak kişi sayısı belirlenmiştir $(\mathrm{n}=$ madde sayısı $\times 25 ; 8 \times 25=$ 200). Örneklem sayısı 200 anne ve 200 babaya ulaşılacak şekilde planlanmıştır (11-13). Çalışmaya hastanenin loğusa servisinde normal vajinal yolla miadında doğum yapan, 2500 gram ve üzerinde ilk bebeği olan, bebeği ile aynı ortamda bulunan (rooming-in), en az okuryazar olan ve araştırmaya katılmayı kabul eden kadınlar ile eşleri dahil edilmiştir.

Araştırma iki aşamada uygulanmıştır. ilk aşamada loğusa servisinde bebekleri en fazla 48 saatlik olan, araştırma kriterlerine uyan ve araştırmaya katılmaya gönüllü anne $(n=296)$ ve eşlerine $(n=215)$ ölçekler uygulanmıştır. Íkinci aşamasında ise 8-10. haftalarda yapılan ev ziyaretleriyle ölçekler tekrar uygulanmıştır. İkinci aşamada anne ve babaların hepsiyle görüşülmek istenmiştir fakat adreste bulunulamaması, adres değişikliği ve zaman sınırlılığı nedeni ile ulaşılabilen 202 anne ve 142 baba ile evlerinde görüşülmüş ve veri toplama işlemi tamamlanmıştır.

Araştırmaya katılan ilk gurup annelerin \% $36.5^{\prime}$ inin ( $\left.n=108\right)$, ikinci grupta ise \%23'nün ( $n=68$ ) lise mezunu; babaların ise \%39.5'i $(n=85)$ ile \%26.9'nun $(n=58)$ lise mezunu olduğu belirlenmiştir. Anne ve babalara gelir düzeyleri sorulduğunda annelerin \%62.8'i ( $n=186)$, babaların ise \%67'si ( $n=144)$ orta düzeyde geliri olduğunu belirtmiştir. Araştırmaya katılan kadınların \%92.5'i (n=272), babaların \%97.7'si ( $n=210)$ evliliklerini isteyerek yapmışlardı. Çiftlerin 216'sı (\%73.0) 1 ya da 2 çocuğa sahiplerdi ve anneler \%80.4'ü ( $n=238$ ) hiç düşük yapmamıştı. Annelerin sadece \%28.7'si ( $n=85)$ doğum olayını mutluluk verici bir olay olarak tanımlamıştır. Annelerin \%81.7'nin ( $n=242)$, babaların \%92.1'nin son gebeliği istedikleri belirlenmiştir. Eşlerin doğum sırasında birbirlerinin yanlarında olma isteği her iki grupta da yakın oranlarda belirlenmiştir (anne $=\% 64$, baba=\%62.8). Çalışmaya katılan annelerin \% 66.2'si (n=196) doğumdan hemen sonra, \% 28.4'ü ( $n=84)$ doğumdan sonraki 1-2 saat içinde bebeğini emzirmiş ve sadece hemen emziren annelerin \%50.2'si (n=16) bebeğe zarar vermekten korktuğu için kucaklayamadığını ifade etmiştir.

Çalışmaya alınan annelerin bebeklerinin tanıtıcı özelliklerine bakıldığında, bebeklerin \% 54.4'nün ( $n=170)$ kız, \%42.6'nın ( $n=126)$ erkek olduğu saptanmıştır. Eşlere istedikleri bebek cinsiyeti sorulduğunda, annelerin \%70.9'nun $(n=210)$, babaların \%72.5'inin $(n=156)$ cinsiyeti önemli bulmadıklarını belirttiği belirlenmiştir.

Araştırmada Kullanılan Ölçüm Araçları: Araştırmanın verilerinin toplanmasında; "Bilgilendirilmiş olur formu", anne-baba ve bebeklerinin tanıtıcı bilgilerinin yer aldığı " Anne-Baba ve Bebek Tanıtıcı Bilgi Formu", $(A B B O ̈)=(\text { The Mother to Infant Bonding Scala })^{\prime \prime}$ 
ve "Edinburgh Doğum Sonrası Depresyon Ölçeği (EDSDÖ)” kullanılmıştır.

Tanıtıcı bilgileri toplamak için geliştirilen tanıtıcı bilgi formu araştırmacı tarafından ön uygulama olarak loğusa servisinde yatan 20 kadına ve eşine uygulanmış, son şekli verilmiştir. Ön uygulama verileri örneklem içine dahil edilmemiştir. Tanıtıcı bilgi formu, annebabaya ve bebeğe ait tanıtıcı özellikleri içeren 8 tane açık uçlu, 24 tane seçenekli toplam 32 sorudan oluşmaktadır.

Anne-Bebek Bağlanma Ölçeği: ABBÖ, doğumdan sonraki ilk günden itibaren uygulanabilecek şekilde düzenlenmiş ve annenin bebeğine karşı hissettiği duyguları tek bir kelime ile ifade etmesine olanak sağlamaktadır. Anne ya da baba tarafından tek başına kolaylıkla ve hızlı bir şekilde uygulanabilecek olan bu ölçek, kurulan bağ ile annenin ilk dönem ruh hali arasındaki ilişkiyi göstermektedir. Taylor ve ark. (5) tarafından geliştirilen ölçeğin özgün adı "Mother-toInfant Bonding Scale"dır. ABBÖ 8 maddeden oluşan, 4'lü likert biçiminde bir ölçektir. Dört seçenekten oluşan yanıtlar 0-3 arasında puanlanmakta, ölçekten alınabilecek en düşük puan 0 ve en yüksek puan 24 olmaktadır. Değerlendirmede 1.,4., ve 6 . maddeler olumlu duygu ifadesi olup $0,1,2,3$ şeklinde puanlanırken; 2.,3.,5.,7. ve 8 . maddeler olumsuz duygu ifadeleri olup 3,2,1,0 şeklinde, ters olarak puanlanmaktadır. Ölçeğin puanlayıcılar arası güvenilirliğinin 0.71 ve iç tutarlık güvenilirliğinin (Cronbach Alpha) 0.66 olduğu bildirilmiştir. Taylor ve ark.'nın (5) yapmış olduğu çalışmada 3. Gün ve 12 . Haftadaki bağlanma skorları arasında güçlü bir korelasyon bulunmaktadır $(r=0.54$ $p<0.001$ ).

\section{Edinburgh Doğum Sonrası Depresyon}

Ölçeği: $\square$ Engindeni ve ark.( ) tarafından Türkçe uyarlaması yapılmış olan ölçek doğum sonrası dönemdeki kadınlarda depresyon riskini belirlemeye yönelik, tarama amaçlı olarak hazırlanmış bir ölçektir.
Ölçek, kendini değerlendirme türünde dörtlü likert tipinde ve 0 maddeden oluşmaktadır. Dört seçenektenoluşan yanıtlar 0-3 arasında puanlanmakta, ölçekten alınabilecek en düşük puan 0 ve en yüksek puan 30 olmaktadır. Değerlendirmede 1.,2., ve 4 . maddeler $0,1,2,3$ seklinde puanlanırken, 3.,5.,6.,7.,8.,9., ve 10. maddeler 3,2,1,0 şeklinde, ters olarak puanlanmaktadır. Engindeniz' in çalışmasında (14) Ölçeğin kesme puanının 12/13, cronbach's alfa güvenirlik katsayısının 0.79 olduğu belirlenmiştir ve ölçek puanı 13 ve daha fazla olan kadınlar risk grubu olarak kabul edilmektedir.

\section{Verilerin Analizi ve Değerlendirilmesi:}

Elde edilen veriler bilgisayar ortamında (SPSS 15.0) değerlendirilmiştir. Çalışmanın birinci aşamasında örneklem grubunun sosyodemografik özelliklerine ait bulgular, tanımlayıcı özellikler sayı ve yüzde olarak verilmiştir.

\section{ABBÖ’nin geçerlik analizlerine yönelik olarak;}

1.Dil eşdeğerliliği; ABBÖ’nin dil geçerliği için, ilk önce çeviri eşdeğerlik çalışması, daha sonra grup çevirisi, uzman görüşü yöntemleri kullanılmıştır $(11,12,15)$.

- Birincil olarak ölçeğin orijinal formu İngilizceyi iyi bilen, alanında uzman (Dördü yurtdışında eğitim almış) yedi akademisyen tarafından bağımsız olarak Türkçeye çevrilmiştir.

- Ölçeğin her maddesini en iyi temsil eden karşılıkları ile Türkçe tek bir metin oluşturulmuştur.

- Metindeki bu maddelerin görünüm geçerliğini değerlendirmek için, İngilizceyi iyi bilen sekiz öğretim üyesinden görüş alınmış,

- Geri çeviri yöntemi ile Türkçe ve İngilizceyi iyi bilen bir dil bilimci tarafından tekrar Ingilizce'ye çevrilerek özgün form ile karşılaştırılmıştır. 
- Türkçe formun ön uygulaması 20 anne

ve 20 babaya uygulanmış ve bu gurup örnekleme dahil edilmemiştir.

\section{2. Ölçeğin geçerlilik incelemesi için içerik}

\section{(Kapsam) geçerliği [Kendall Uyuşum Katsayısı (W)]:}

Faktör Analizi-Temel bileşenler analizi kullanılmıştır. İçerik geçerliliğini sağlamak için "uzman kişiye danışma" yöntemi uygulanmış, sekiz hemşirelik ve ebelik öğretim üyesinin görüş ve önerileri alınmıştır. Ölçekteki her bir maddenin anlaşııır olup olmadığı konusunda, annenin bebeğe bağlanma derecesi olarak 1 ile 5 arasında puan vererek değerlendirmeleri istenmiştir. Uzman görüşlerinin değerlendirilmesi Kendall Uyuşum Katsayısı (W) korelasyon testi uygulanarak yapılmıştır.

$\begin{array}{cll}\text { Ölçeğin } & \text { geçerlik çalışması } & \text { yapı } \\ \text { geçerliğine } & \text { temellendirilmiştir. } & \text { Yapı }\end{array}$
geçerliğinde $A B B O ̈$ ile depresyon ölçeği arasındaki ilişki, depresyonu olan ve olmayanları ayırt etme durumu incelenmiştir. EDSDÖ'ye yönelik olarak ise KolmogorovSmirnov $Z$ testi, Mann Whitney $U$ testi ve regresyon analizi kullanılmıştır $(11,12,15)$.

\section{3. Ölçeğin Güvenirliği incelemesinde ise;} madde istatistiklerinin hesaplanması, doğrudan teste konulabilecek maddelerin seçilmesi, düzeltilerek teste konulabilecek maddelerin belirlenmesi ve bu maddeler üzerinde yapılacak düzeltme çalışmalarının ne doğrultuda olacağının saptanması, teste konulması mümkün olmayan maddelerin ayıklanması amacıyla madde analizleri yapılmıştır $(11,12,15)$.

\section{Güvenirlilik analizlerinde;}

- Ölçeğin zamana karşı değiş̧mezliği (test-tekrar test güvenirliliği) incelemesi olarak "Aralıklı Yöntem" kullanılmış (8-10 hafta sonra testler tekrarlanarak) ve Pearson's Momentler Çarpımı Korelasyon analizi yapılmıştır.
- İç tutarlılık kapsamında Cronbach Alfa katsayısı ve madde toplam korelasyonu değerlerine bakılmış ve Cronbach Alpha katsayıları "Madde Toplam Puan Korelasyon Tekniği" ile incelenmiştir $(11,12,15)$.

\section{Araştırmanın Etiği:}

Araştırmada kullanılacak ölçeğin geçerlik ve güvenirlik çalışmasının yapılabilmesi için elektronik posta yolu ile Dr. Alyx TaylorVieira'dan izin alınmıştır. Çalışmanın uygulanabilmesi için İ Sağ|ık Müdürlüğü ve ilgili hastaneden yazılı izin alınmıştır. Ayrıca anne ve babalarla görüşülerek araştırmanın amacı, araştırmada sağlanacak yararlılıklar hakında bilgilendirilmiş ve onamları alınmıştır. Çalışmanın yapıldığı dönemde ilde yerel etik kurulu olmadığından etik kurul izni alınamamıştır.

\section{BULGULAR}

\section{Ölçek Dil Geçerliği:}

Ölçeği Türkçeye kazandırmak için ilk önce çeviri eşdeğerlik çalışması yapılmıştır. Formun Türkçeye uyarlanmasında grup çevirisi, uzman görüşü yöntemleri kullanılarak, önce ölçeğin orijinal formu İngilizceyi iyi bilen, alanında uzman (Dördü yurtdışında eğitim almış) yedi akademisyen tarafından bağımsız olarak Türkçeye çevrilmiştir. Bu çeviriler karşılaştırılıp tartışılarak her maddeyi en iyi temsil eden karşılıkları ile Türkçe tek bir metin oluşturulmuştur. Daha sonra bu metin maddelerinin görünüm geçerliğini değerlendirmek için, İngilizceyi iyi bilen sekiz öğretim üyesinden görüş alınmıştır. Ölçek geri çeviri yöntemi ile Türkçe ve İngilizce'yi iyi derecede bilen bir dil bilimci tarafından tekrar Ingilizce'ye çevrilmiştir ve özgün formu ile karşılaştırılmıştır. Bu doğrultuda ABBÖ'nin Türkçe formu, orijinal maddeleri en iyi temsil ettiği bildirilen ifadeler seçilerek oluşturulmuştur. Ölçeğin Türkçe formu 20 anne ve 20 babaya ön uygulama şeklinde uygulanarak anlaşılırlığı değrlendirilmiş ve son hali elde edilmiştir. Ön uygulama verileri örneklem içine dahil edilmemiştir. 


\section{Ölçek Iç̧ Geçerliği ( Kapsam Geçerliği):}

$\mathrm{Bu}$ araştırmada içerik geçerliliğini sağlamak için "uzman kişiye danışmak" yöntemi uygulanmış ve orijinal ölçekteki maddelere denk olan Türkçe'deki karşılıklarına ulaşılması hedeflenmiştir.

Anne- Bebek Bağlanma ölçeğinin Türkçe formunun içerik geçerliliği açısından 8 hemşirelik ve ebelik öğretim üyesinin, ölçekteki her bir maddenin anlaşılır olup olmadığı konusunda görüş ve önerileri alınmıştır. Her bir maddeye annenin bebeğe bağlanma derecesi olarak 1 ile 5 arasında puan vererek değerlendirmeleri istenmiştir. Uzmanlar arasında görüş birliğine varma durumlarını incelemek amacıyla yapılan, ABBÖ Kendall Uyuşum Katsayısı (W) korelasyon testi uygulanmıştır ve analiz sonucunda uzmanların maddelerin içeriği konusunda görüş birliğine vardıkları görülmüştür $(X 2=15.520, S D: 7, \quad W=0,277$, $p=0,030)(p<0,05)$.

\section{GÜVENIRLIK}

\section{Ölçeğin Faktör Yapısı:}

Yapı geçerliğini belirlemede faktör analizi ve birleşene ayırt eden geçerlik, bilinen grup karsılaştırması ve hipotezin test edilmesi gibi çeşitli yöntemler kullanıır. En sık kullanılan yöntem faktör analizidir.

Temel Ön uygulama verileri örneklem içine dahil edilmemiştir. Bileşenler analizi sonucunda doğumdan sonraki birinci gün içerisinde uygulanan ölçekten elde edilen verilerin iki faktörden oluştuğu ve toplam varyansı \%48.9 oranında ölçtüğü anlaşılmaktadır. Döndürülmemiş (Yönlendirilmemiş) bileşen matrisi incelendiğinde ölçeğin 2 faktörden oluştuğu, belirgin bir faktör yapısı elde edilmediği görülmüştür. Varimax yöntemi ile yapılan yönlendirme sonucunda "Sevgi dolu, Nötr / hiçbir şey hissetmeme, Sevinçli, Hoşlanmama, Koruyucu" maddelerinin birinci faktör; "Kızgın, Hayal kırıklığı ve Öfke" maddelerinin ikinci faktör altında yer aldığı gözlenmiştir. Buna göre anneler beklentilerinin karşılanmaması sonucu ortaya çıkan hisleri diğerlerinden ayırmaktadırlar. Burada sadece hoşlanmama maddesinin birinci faktör altında yer alması annelerin bu konudaki hislerinin karmaşık olduğunu göstermektedir. 8-10 hafta sonra annelere uygulanan ölçekten elde edilen verilerde değerler iki faktörden oluşmuş ve toplam varyansı \% 49.2 oranında ölçmüştür.

Varimax yönlendirme metodu sonucunda "Sevgi dolu, Nötr / hiçbir şey hissetmeme, Sevinçli, Koruyucu" maddelerinin birinci faktör, "Kızgın, Hoşlanmama, Hayal kırıklığı ve Öfke" maddelerinin ikinci faktör altında yer aldığı gözlenmiştir. Buna göre doğumdan 8-10 hafta sonra annelerin beklentilerinin doğumdan sonra karşılanmaması hisleri daha da belirginleşmiştir (Tablo 1).

Toplam varyans tablosundaki değerlerden babalara doğumdan sonraki birinci gün içerisinde uygulanan anketten elde edilen verilerin iki faktörden oluştuğ u ve toplam varyansı \%68.6 oranında ölçtüğü gözlenmektedir. Temel bileşenler analizi sonucunda, belirgin bir faktör yapısı elde edilememiştir. Veriler bu nedenle Varimax Yönlendirme metodu yöntemi ile değerlendirilmiş ve sonucunda "sevgi dolu maddesinin" her iki faktörde de yüksek yükleme değerine sahip olduğu gözlenmiştir. "Nötr / hiçbir şey hissetmeme, Sevinçli, Hoşlanmama, Kızgın, Hayal kırıklığı ve Öfke" maddelerinin birinci faktör, "Koruyucu" maddesinin ikinci faktör altında yer aldığı gözlenmiştir. Buna göre babaların koruma hissini diğer hislerden belirgin bir şekilde farklı algıladıkları söylenebilir.

Babalara doğumdan 8-10 hafta sonar tekrar uygulanan anketten elde edilen verilerin iki faktörden oluştuğu ve toplam 
Tablo1: ABDÖ Annelerde Döndürülmemiş (Yönlendirilmemiş) Temel Bileşenler (Faktör) Analizi

Sonucu Maddelerin Aldıkları Yükler

\begin{tabular}{|c|c|c|c|c|c|}
\hline \multirow[t]{2}{*}{ Maddeler } & \multicolumn{2}{|c|}{$\begin{array}{l}\text { A Bileşeni* (Doğumdan } \\
1 \text { Gün Sonra) }\end{array}$} & \multicolumn{3}{|c|}{$\begin{array}{l}\text { B Bileşeni** (Doğumdan 8-10 } \\
\text { Gün Sonra) }\end{array}$} \\
\hline & 1.Faktör & 2. Faktör & 1.Faktör & 2.Faktör & 3.Faktör \\
\hline $\begin{array}{l}\text { ANNELER } \\
\text { Sevgi dolu } \\
\text { Kızgın } \\
\text { Nötr/Hiçbir şey hissetmeme } \\
\text { Sevinçli } \\
\text { Hoşlanmama } \\
\text { Koruyucu } \\
\text { Hayal kırıklığ } \\
\text { Öfke } \\
\text { BABALAR } \\
\text { Sevgi dolu } \\
\text { Kızgın } \\
\text { Nötr/Hiçbir şey hissetmeme } \\
\text { Sevinçli } \\
\text { Hoşlanmama } \\
\text { Koruyucu } \\
\text { Hayal kırıklığı } \\
\text { Öfke }\end{array}$ & $\begin{array}{l}.717 \\
.392 \\
.559 \\
.707 \\
.713 \\
.591 \\
.511 \\
.321 \\
\\
.833 \\
900 \\
.366 \\
.904 \\
467 \\
.361 \\
.889 \\
.851\end{array}$ & $\begin{array}{l}-.090 \\
.372 \\
-.097 \\
-.201 \\
-.152 \\
-.449 \\
.491 \\
.740 \\
\\
.312 \\
-.310 \\
.070 \\
.173 \\
-.102 \\
.865 \\
-.075 \\
-.423\end{array}$ & $\begin{array}{l}.675 \\
.592 \\
.463 \\
.561 \\
.631 \\
.486 \\
.658 \\
.527 \\
\\
.642 \\
.556 \\
.556 \\
.686 \\
.726 \\
.097 \\
.554 \\
.772\end{array}$ & $\begin{array}{l}.373 \\
-.435 \\
.150 \\
.520 \\
-.116 \\
.481 \\
-.400 \\
-.478 \\
\\
-.377 \\
.817 \\
.817 \\
-.326 \\
-.291 \\
.236 \\
-.121 \\
-.243\end{array}$ & $\begin{array}{l}-.475 \\
-.114 \\
-.114 \\
-.398 \\
.216 \\
.289 \\
.664 \\
.196\end{array}$ \\
\hline $\begin{array}{l}\text { Tüm Faktörlerin Açıkland } \\
\text { Toplam Varyans (\%) } \\
\text { Anne } \\
\text { Baba }\end{array}$ & $\begin{array}{l}48.88 \\
68.60\end{array}$ & & $\begin{array}{l}49.18 \\
71.96\end{array}$ & & \\
\hline
\end{tabular}

varyansı \% 71.96 oranında ölçtüğü görülmektedir. Temel bileşenler analizi sonrasında elde edilen bileşen matrisinde de ölçeğin 3 faktörden oluştuğu anlaşılmakla birlikte, belirgin bir faktör yapısı elde edilememiştir. Varimax Yönlendirme metoduna göre "Koruyucu" maddesinin her üç faktörde de yüksek yükleme değerine sahip olduğu gözlenmiştir. Kızgın, Nötr / hiçbir şey hissetmeme maddelerinin birinci faktör, Sevgi Dolu ve Sevinçli maddeleri ikinci faktör, Hoşlanmama, Hayal kırıklığı ve Öfke maddeleri üçüncü faktör altında yer almıştır.

Temel bileşenler analizinden elde edilen bulgular bir bütün olarak değerlendirildiğinde bağlanma ölçeğinin annelere uygulanmasındanelde edilen verilerin güçlü bir faktör yapısı oluştururken, aynı durumun babalar için geçerli olmadığı söylenebilir. Bu farklılaşmanın temelinde, anne beklentilerinin karşılanma durumunun yattığı söylenebilir. Ölçeğin güvenirliğini belirlemek amacı ile annelerde ilk test için Cronbach Alpha .695 olarak bulunmuştur.8-10 hafta sonra uygulanan test tekrar test güvenilirlik korelasyon değeri .683 bulunmuştur. Ölçeğin babaya ait Cronbach Alpha katsayısı, ilk test için Cronbach Alpha .798 ve ikinci test uygulaması için Cronbach Alpha .718 bulunmuştur (Tablo 2).

Güvenirlik analliz bulguları bir bütün olarak değerlendirildiğinde, ölçeğin anneler uygulanması ile elde edilen verilerin daha küçük iç tutarlılığa sahip olduğu ve buna 
Tablo2: Anne-Bebek Bağlanma Ölçeği Anneye ve Babaya Ait Test tekrar Test (I. ve II. Uygulama) Cronbach Alpha Güvenirlik Katsayı Sonuçları

\begin{tabular}{|l|l|l|l|}
\hline $\begin{array}{l}\text { Anne-Bebek } \\
\text { Bağlanma Ölçeği }\end{array}$ & Madde sayısı & Cronbach Alfa & N \\
\hline ANNE & & .695 & \\
I.UYGULAMA & 8 & .683 & 296 \\
II. UYGULAMA & 8 & & 202 \\
\hline BABA & & .798 & \\
I.UYGULAMA & 8 & .718 & 215 \\
II. UYGULAMA & 8 & & 142 \\
\hline
\end{tabular}

rağmen tüm maddelerin ölçeğin tutarlılığına katkı sağladıkları saptanmıştır. Babalara uygulanan anketlerden elde edilen veriler daha yüksek güvenirliğe sahip olmakla birlikte, "nötr/hiçbirşey hissetmeme, hoşlanmama ve koruyucu" maddelerinin ise ölçeğin güvenirliğine katkı sağlamadığı belirlenmiştir. Bu ölçeğin güvenirlik açısından, babaların bebeklerine bağlılık düzeyini ölçmede katkı sağlamadığı söylenebilir.

Annenin ilk ve son testlerdeki depresyon düzeyi arttıkça bebeğe duyulan bağlıı̆̆ı etkilemediği, aralarındaki farkın anlamlı olmadığı belirlenmiştir (illk test $\mathrm{Z}=-1.782, \mathrm{p}=.075$; Sontest $t=-0.208, p=0.836, p>0.05$ ) (Tablo 3).

Tablo 3. Anneye ve Babaya Ait Annenin Doğumdan Sonra Depresyon Düzeyi ile Bebeğe Duyulan Bağlanma Arasındaki İlişki ve Bağlılığın Değişimi

\begin{tabular}{|c|c|c|c|}
\hline Uygulama Yapılan Gruplar & Depresyon Ölçeği & $\mathbf{N}$ & $\begin{array}{l}\mathbf{Z}^{*} \\
\mathbf{P}\end{array}$ \\
\hline \multirow[t]{2}{*}{$\begin{array}{l}\frac{\text { ANNE }}{\text { ABBÖ Anne İlk }(N=256)} \\
\text { ABBÖ Anne Son }(N=202)\end{array}$} & $\begin{array}{l}\text { Düşük } \\
\text { Yüksek }\end{array}$ & $\begin{array}{l}146 \\
150\end{array}$ & $\begin{array}{l}Z=-1.782 \\
p=.075\end{array}$ \\
\hline & $\begin{array}{l}\text { Düşük } \\
\text { Yüksek }\end{array}$ & $\begin{array}{l}101 \\
101\end{array}$ & $\begin{array}{l}\mathrm{t}=--0,208^{* *} \\
\mathrm{p}=.0,836\end{array}$ \\
\hline \multirow{2}{*}{$\begin{array}{l}\frac{\text { BABA }}{\text { ABBÖ Baba İlk }(N=215)} \\
\text { ABBÖ Baba Son }(N=142)\end{array}$} & $\begin{array}{l}\text { Düşük } \\
\text { Yüksek }\end{array}$ & $\begin{array}{l}56 \\
159\end{array}$ & $\begin{array}{l}Z=-2.447 \\
p=.014\end{array}$ \\
\hline & $\begin{array}{l}\text { Düşük } \\
\text { Yüksek }\end{array}$ & $\begin{array}{l}30 \\
112\end{array}$ & $\begin{array}{l}Z=-8.442 \\
p=.000\end{array}$ \\
\hline
\end{tabular}

*Annenin doğum sonrasındaki 8-10 hafta içinde çocuğuna karşı hissettiği bağlılık hissi ile depresyon düzeyi arasındaki ilişkide normallik varsayımı sağlandığı için parametrik bir test olan bağımsız örneklem t-testi kullanılmıştır.

** Anne-Babanın doğum sonrasındaki çocuğuna karşı hissettiği bağlılık hissi ile depresyon düzeyi arasındaki ilişkide normallik varsayımı sağlanamadığı için non-parametrik bir test olan MannWhitney U testi kullanılmıştır. 
Babanın ilk testlerdeki depresyon düzeyi ile bebeğe bağlanmaları arasındaki ilişki değerlendirildiğinde; sözkonusu değişkenler arasındaki ilişki istatistiksel olarak negatif yönde ve anlamlı bulunmuştur $(Z=-2.447, \quad p=0.014) \quad(p>0.05)$. Babalardaki depresyon düzeyi arttıkça bebeğe duyulan bağlılık azalmaktadır. Babalara 8-10 hft sonra uygulanan testlerdeki depresyon düzeyi ile bebeğe bağlanmaları arasındaki ilişki değerlendirildiğinde; depresyon düzeyi düşük babaların çocuklarına daha iyi bağlandıkları, değişkenler arasındaki ilişkinin istatistiksel olarak negatif yönde, güçlü ve anlamlı olduğu bulunmuştur $(Z=-8.44, \quad p=0.00) \quad(p>0.01)$ (Tablo 3). Babalardaki depresyon düzeyi düştükçe, bebeğe duyulan bağlılık artmaktadır. Bu bulgulara göre, annelerin bağlanma düzeyinde zaman içerisinde anlamlı olmayan kısmi bir azalma yaşanırken, babaların bağlanma düzeyinde ise zaman içerisinde belirgin ve anlamlı bir düşüş olduğu gözlenmiştir.

\section{Ölçeğin Zamana Karşı Değişmezliğine ilişsin Bulgular (Test Tekrar Test Güvenilirlik):}

Zamana karşı değişmezliği belirlemek için ölçek "Aralıklı Yöntem" kullanılmış ve 8-10 hafta sonra yeniden aynı gruba uygulanmıştır. $\mathrm{Bu}$ sonuçlar "Pearson Momentler Çarpımı Korelasyon Tekniği” kullanılarak analiz edilmiştir.

Anne ve babalara doğumdan sonra birinci gün içinde ve 8-10 hafta sonra uygulanan anket sonuçlarına göre; doğumdan sonrasındaki birinci günde annelere uygulanan ABBÖ'ni oluşturan maddeler arasındaki 23 ilişkiden sadece 5 tanesinin istatistiksel olarak anlamlı olmadığı belirlenmiştir. Doğumdan 8-10 hafta sonra annelere uygulanan ölçeği oluşturan maddeler arasındaki 23 ilişkiden sadece 3 tanesi istatistiksel olarak anlamlı bulunmamıştır.
Babalara doğum sonrasındaki birinci gün içinde uygulanan ölçeği oluşturan maddeler arasındaki 23 ilişkiden 5'nin anlamlı olmadığı belirlenmiştir. Babalara doğumdan 8-10 hafta sonra uygulanan ABBÖ'ni oluşturan maddeler arasındaki 23 ilişkiden 12 tanesi istatistiksel olarak anlamlı değildir.

$\mathrm{Bu}$ bulgular bir bütün olarak değerlendirildiğinde ABBÖ’nin maddeler arası ilişki düzeyinin annelere yapılan her iki uygulamada, babalara yapılan ilk uygulamada yüksek çıktığı gözlenmektedir. Ölçeği oluşturan maddeler ölçülmek istenen bağlanma kavramına katkı sağlarken, özellikle annelerde ölçeğin güvenilirliğini desteklediği söylenebilir.

Ölçek annelerde daha düşük iç tutarlığa sahip olmasına rağmen, tüm maddelerin ölçeğin tutarlığına katkı sağladıkları saptanmıştır (Madde bütün korelasyon katsayıları: $r=.21-.54$ arasında, madde silindiğinde $\mathrm{CA}=.62-.69$ arasında).

\section{TARTIŞMA}

"Anne-bebek Bağlanma Ölçeği'nin" geçerlik ve güvenirlik analiz sonuçları literatür ile karsılaştırılarak incelenmiştir. Ancak bu alanda çok az sayıda çalışma olması nedeniyle tartışma sınırlı sayıda literatürle yapılabilmiştir. Geçerlik ölçme, aracın bir özelliği değil ölçülmek istenen özelliği tam ve doğru biçimde ölçmesidir. Ölçeklerin dil ve kültürel adaptasyonuna yönelik uluslararası metodolojik öneriler uyarınca Türkçeye kazandırmak için çeviri eşdeğerlik çalışması yapılmıştır. Ölçeğin geçerlik çalışmasında sırasıyla dil geçerliği, içerik geçerliği ve yapı geçerliği analizleri değerlendirilmiştir. Ülkemizde yapılan ölçek uyarlama çalışmalarında ilk olarak dil geçerliğine bakıldığı bilinmektedir $(16,17)$. Farklı kültür ve dillerde geliştirilmiş olan ölçekler ülkemize uyarlanırken kültüre ve dile göre uygulanabilir olması gerekmektedir. Bu nedenle dile bağı olarak o ölçeğin kavramlaştırma ve anlatım farklılıklarının 
incelenmesi, çevrilen dilde anlamlı olması beklenir. Bu çalışmada ulusal ve uluslararası metadolojik öneriler uyarınca çeviri eşdeğerlik çalışması yapılmıştır. İçerik geçerliği ölçme aracında bulunana maddelerin ölçülmek istenen kavramı ne düzeyde temsil ettiğinin gösterir. Bu amaçla kullanılan en sık yöntem uzman görüşlerinin alınmasıdır (16). Bir ölçeğin geçerliğini değerlendirmede en çok tercih edilen kapsam geçerliğine yönelik (17) Kendall W uyum testi yapılmış ve test sonucunda 8 uzman görüş birliğine varmış ve ölçekte yer alan ifadelerin kültürümüze uygun olduğu ve ölçmek istenilen alanı temsil ettiği belirlenmiştir.

Yapı geçerliği, ölçme aracının ölçtüğünü iddia ettiği teorik yapıyı ne derece ölçebileceğini gösterir. Ölçeğin faktör yapısının belirlenmesinde temel bileşenler analizi yöntemi kullanılmıştır. Bulgular bir bütün olarak değerlendirildiğinde bağlanma ölçeğinin annelere uygulanması sonucunda iki faktörlü bir ölçek yapısının varlığını gözlenmektedir. Bu farklılaşmanın temelinde ise Taylor ve ark.'nın (5) çalışmasına paralel olarak annenin beklentilerinin karşılanma durumunun yattığı söylenebilir. Bağlanma ölçeğinin babalara uygulanması sonrasında ise ilk uygulama verilerinden iki faktörlük, ikinci uygulamadan ise 3 faktörlük bir sonuç elde edilmiştir. Ayrıca sevgi dolu ve koruyucu maddelerinin herhangi bir faktör üzerinde yüksek yükleme değerine sahip olmadıkları gözlenmiştir. Figueiredo ve ark. (19) çalışmasında, uygulanan yapı geçerliliği analizinde "АВBÖ" geliştirilerek Portekizce versiyonu olan "Yeni Bir ABBÖ" oluşturulmuştur. Bu ölçek 12 maddeden oluşmaktadır ve "olumlu bağ", "olumsuz bağ" ve "belirgin olmayan bağ" olmak üzere 3 temel grup oluşturulmuştur. Çalışma sonucunda annelerin $\% 71^{\prime} i$, babaların $\% 73^{\prime} u ̈$ olumlu duygular taşımıştır. Anne ve babanın bebeğe karşı hissettikleri olumlu olumsuz duygulanmalar büyük oranda benzerdir.
Ancak çalışma sonuçları annelerin babalara göre daha düşük yükleme değerine sahip olduklarını göstermiştir. Bu araştırma kapsamına alınan anne ve babalarla, Figueiredo ve ark.'nın (19) yapmış olduğu çalışma paralellik göstermemektedir. Temel bileşenler analizinden elde edilen veriler bir bütün olarak değerlendirildiğinde bağlanma ölçeğinin annelere uygulanmasından elde edilen verilerin güçlü bir faktör yapısı oluştururken, aynı durumun babalar için geçerli olmadığı söylenebilir.

Zamana karşı değişmezliği belirlemek için ölçek "Aralıklı Yöntem" kullanılarak 8-10 hafta sonra yeniden aynı gruba uygulanmış ve sonuçlar 'Pearson Momentler Çarpımı Korelasyon Tekniği' kullanılarak analiz edilmiştir. Taylor ve ark. (5) çalışmasında da zaman karşı değişmezliği belirlemek için aralıklı yöntem kullanılmış ve bebeğin doğumdan sonraki 3 . günde, ilk birkaç hafta içerisinde ve 12 . Haftada ABBÖ aynı gruba uygulanmış, aynı teknikle analiz edilmiştir. Onikinci haftada elde edilen ortalama sonuçlar 3. günde kaydedilen sonuçlardan $\% 67$ daha düşük bulunmuştur. Bu durum anne ile bebek arasında kurulan bağın iki dönem arasında büyük bir gelişme kaydettiğini göstermektedir. Figueiredo ve ark. (19) yaptıkları çalışmada, ölçeği doğumdan sonra ilk 24 saat ve doğumdan 48 saat sonra olmak üzere iki kez anne ve babalara uygulamıştır. Maddeler arası ilişki düzeyinin annelere yapılan ilk uygulamada düşük, ikinci uygulamada yüksek, babalara yapılan iki uygulamada da yüksek çıktığı belirtilmiştir (19). Bu çalışmadaki bulgular diğer çalışmadan farklı olarak (19), bir bütün halinde değerlendirildiğinde, ölçeği oluşturan maddelerin ölçülmek istenen bağlanma kavramına katkı sağladığı ve ölçeğin güvenilirliğini özellikle annelerde desteklediği söylenebilir.

ABBÖ'nüin anneye ait Cronbach Alpha katsayıları incelendiğinde, doğumdan sonraki birinci gün içindeki Cronbach Alpha katsayısı 0.695 ve doğumdan 8-10 hafta sonra Cronbach 
Alpha katsayısı 0.683 olarak bulunmuştur. ABBÖ'nün babaya ait Cronbach Alpha katsayıları doğumdan sonra birinci gün içinde 0.798 ve doğumdan 8-10 hafta sonra 0.718 olarak bulunmuştur. Orjinal ölçekte de annelere ait Cronbach Alpha katsayısı 0.71 olarak saptanmıştır (5). Literatürde güvenilirliğin 0.70 - 0.80 arasında değer alması ölçme aracının araştırmalarda kullanılması için yeterli olduğunu göstermektedir (18). Cronbach Alpha katsayısı 0.60-0.80 ise ölçek oldukça güvenilir, 0.80-1.00 ise ölçek yüksek derece güvenilir bir ölçek olarak kabul edilir (17). Çalışma kapsamında anne/babalara ait Cronbach Alpha katsayıları incelendiğinde, Taylor ve ark.'nın (5) yapmış olduğu çalışma ve literatürle uyumlu olduğu ve bu ölçeğin güvenilir olduğu söylenebilir (17).

ABBÖ'yü oluşturan maddelerin güvenilirlik düzeyine etkileri (Madde Toplam Korelasyon Sonuçları), madde silindiği ve Cronbach Alpha değerleri incelendiği zaman tüm maddelerin ölçeğin güvenilirliğine katkı sağladığı, dolayısıyla herhangi bir maddenin anketten çıkarılmasının güvenilirliği arttırmayacağı gözlenmektedir. Güvenilirlik analizi bulguları bir bütün olarak değerlendirildiğinde anketin annelere uygulanması ile elde edilen verilerin daha düşük iç tutarlılığa sahip olmasına rağmen tüm maddelerin ölçeğin tutarlılığına katkı sağladıkları anlaşımaktadır. Ayrıca annelere ilk birinci gün ve 8-10 hafta sonra uygulanan anketten elde edilen güvenilirlik değerleri Taylor ve ark.'nın (5) çalışmasındaki değerlere yakın güvenilirlik değerlerine sahiptir. Babalara uygulanan anketlerden elde edilen veriler daha yüksek güvenilirlik değerlerine sahip olmakla birlikte bazı maddelerin ölçeğin güvenilirliğine katkı sağlamadıkları belirlenmiştir. Bu bulgu ölçeğin babaların bağlılık düzeyini ölçmede güvenilirlik açısından bir takım problemlere sahip olduğunu ortaya koymaktadır. Bu sonuç Figueiredo ve ark. 'nın (19) çalışma sonuçlarından tamamen farklıdır. Taylor ve arkadaşlarının (5) çalışmasında ilk güvenilirlik analizinde 9 maddeden oluşan ABBÖ uygulanmış ve "sahip olmak (Possesive)" maddesinin güvenilirliğe katkı sağlamadığı belirlenmiştir. Bu yüzden anketin bölümleri arasındaki korelasyon değerlendirilmiş ve bunun için de çok boyutlu analiz yöntemleri kullanılmıştır. Ölçekden bir madde çıkartılarak 8 madde şeklinde yeniden düzenlenmiş ve 3 . Günde $r=0.57$, ilk birkaç hafta içerisinde $r=0.61$ ve 12 . haftada $r=0.54$ olarak belirlenmiştir. $\mathrm{Bu}$ çalışma sonuçlarını desteklemektedir.

Çalışmada EDSDÖ'den alınan puanlar yüksek ve düşük olarak iki kategoriye ayrılmış ve depresyon düzeyi ile çocuğa duyulan bağlılık arasındaki ilişki olup olmadığı test edilmiştir Sonuçları bir bütün olarak değerlendirildiğinde, annelerde depresyonun bağlanma üzerindeki etkisinin zamanla kaybolduğu, babalarda ise yüksek depresyonun bebeğe olan bağlanmayı azalttığı gözlenmektedir. Yüksek depresyona sahip babaların bebeklerine daha az bağlı oldukları diğer araştırmalarla uyumludur $(5,19)$. Ayrıca annenin ilk zamandaki depresyonunun kızgınlık olarak dışa vurumu ve bunun sonucunda, bağlanmada geçici bir azalma görülse de bu azalma zaman içersinde dengelenmiş ve depresyonun etkisi ortadan kalkmıştır. Elde edilen sonuçların diğer araştırmalarla uyumlu olması annebebek bağlanma ölçeğinin güvenilirlik ve geçerliğini desteklemektedir.

Annelerin depresyon ölçeğinden aldıkları ortalama puanlar ilk birinci gün içinde 25.5 iken, 8-10 hafta sonra 25.6 olduğu, babaların bağlanma ölçeğinden aldıkları ortalama puanlar ilk 1. gün içinde 27.2 iken, 8-10 hafta sonra 27.7 olduğu görülmektedir. Gözlenen farklılıkların rastlantısal olup olmadığını belirlenmek için eşleştirilmiş örneklem t-testi yapılmış ve annelerin bağlanma düzeyindeki değişim $(p<0.05)$ ile babaların bağlanma düzeyindeki değişim anlamlı bulunmuştur ( $p<0.001)$. Depresyon düzeyindeki farklılıklar ise istatistiksel 
olarak anlamlı değildir ( $p>0.001)$. Bu bulgudan hareketle annelerin bağlanma düzeyinde zaman içersinde kısmi bir azalma yaşanırken babaların bağlanma düzeylerinin zaman içersinde belirgin bir şekilde düştüğü sonucuna varılmıştır. Mevcut literatürle uyumlu olan bu bulgular ölçeğin güvenilirlik ve geçerliğini desteklemektedir $(5,19)$.

\section{SONUÇ:}

ABBÖ en az okuma-yazması olan annelerin bebeklerine bağlanma düzeylerini ölçmede geçerli ve güvenilir bir araçtır. Bu ölçek, babaların bebeklerine bağlanma düzeylerini ölçmede geçerli, ancak güvenilir (iç tutarlık) olmayan bir araçtır. Çalışmanın daha geniş gruplarda, farklı bölgelerde anne ve babaların aynı örneklem içerisinde dahil edilerek değerlendirilmesi önerilir.

\section{KAYNAKLAR}

1. Soysal AS, Bodur S, İşeri E, Şenol, S. Bebeklik dönemindeki bağlanma sürecine genel bir bakış. Klinik Psikiyatri Dergisi 2005;8(2):88-99.

2. Görak G.Yenidoğan Hemşireliğinde Etik. In: Dağoğlu $T$, Görak G. eds. Temel Neonatoloji ve Hemşirelik Ilkeleri. Nobel Tıp Kitabevi: İstanbul, 2002:31-40.

3. Çoban A, Saruhan A. Anne-bebek etkilesiminde hemşirenin rolü. Ege Üniversitesi Hemşirelik Yüksek Okulu Dergisi 2005; 89-96.

4. Kennell JH, Klaus MH. Bonding: recent observations that alter perinatal care. Pediatrics in Review 1998;19(1):4-12.

5. Taylor A, Atkins R, Kumar R, Adams D, Glover V. A new Mother-to-Infant Bonding Scale: links with early maternal mood. Arch Womens Mental Health 2005;8: 45-51.

6. Beck CT. Postpartum depression: Stopping the thief that steals motherhood. AWHONN Lifelines 1999;3(4): 41.

7. Beck CT, Gable RK. Postpartum Depression Screening Scale: Development and psychometric testing. Nursing Research 2000;49(5): 272.

8. McCoy SB, Beal JM, Shipman SB. Risk factors for postpartum depression: a retrospective investigation at 4-weeks postnatal and a review of the literature. JAOA 2006;106(4):193-198.

9. Kennedy HP, Beck CT, Dricoll JW. A light in the fog: Caring for women with postpartum depression. Journal of Midwifery, Women's Health 2002;47(5):318.
10. Lowdermilk DL, Perry SE, Bobak IM. Maternity and women's healt care.7. baskı, Mosby: St. Louis, 2000: 639640,940-963.

11. Büyüköztürk S. Sosyal bilimleri için veri analizi el kitabı istatistik araştırma deseni-SPSS uygulamaları ve yorum. Ankara: Pegem Yayıncılık, 2002.

12. Ercan İ, Kan İ. Ölçeklerde güvenilirlik ve geçerlik. Uludağ Universitesi Tıp Fakultesi Dergisi 2004;30 (3): 211-216.

13. Özdamar K. Paket programlar ile istatistiksel veri analizi-2 (çok değişkenli analizler). 5. Baskı, Eskisehir: Kaan Kitabevi, 2004:236-277.

14. Engindeniz AN, Küey L, Kültür, S. Edinburg doğum sonrası depresyon ölçeği Türkçe formu geçerlilik ve güvenirlik çalışması. Bahar Sempozyumları 1. Kitabı. Ankara: Psikiyatri Derneği Yayınları, 1997:51-52.

15. Büyüköztürk $S$. Faktör Analizi: Temel kavramlar ve ölçek geliştirmede kullanımı. Eğitim Yönetimi Dergisi 2002; Güz: 470-433.

16. Aksayan $S$, Gözum S. Kültürlerarası ölçek uyarlaması için rehber I, Hemşirelikte Araştırma Dergisi 2002;4(1):9-14.

17. Gözüm $S$, Aksayan $S$. Kültürlerarası ölçek uyarlaması için rehber II: Psikometrik özellikler ve kültürlerarası karşılaştırma. Hemşirelikte Araştırma ve Geliştirme Dergisi 2003; (1): 3-14.

geçerlilik. Ankara:Seçkin Yayıncılık San.Tic. A.Ş., 2005.

18. Şencan $H$. Sosyal ve davranışsal ölçümlerde güvenirlik ve

19. Figueiredo B,Costa R, Pacheco A,Pais A. Mother-to-infant and father-to-infant initial emotional involvement. Early Child Development and Care 2007;177(5):521-532. 